\title{
EFEKTIFITAS ATRAKTAN PADA FLY TRAP TERHADAP JUMLAH LALAT RUMAH (MUSCA DOMESTICA)
}

Fikri Kelana Putra, Deri Kermelita, Jubaidi

\author{
Politeknik Kesehatan Kementerian Kesehatan Bengkulu, Jurusan Kesehatan Lingkungan, \\ Jalan Indragiri Nomor 3 Padang Harapan Bengkulu \\ e-mail:fikry_thula@yahoo.com
}

\begin{abstract}
This study aims to determine the effectiveness of organic waste attractants, fish, and tempeh (fermented soybean cake) on the fly trap to the number of flies in the house that caught in Fish Auction Place (TPI) Pulau Baai Bengkulu city.

The research method is a Quasi Experiment (quasi experimental) research design Posttest Only Control Group Design. Research analysis using One Way Anova test and followed by LSD test. This study uses 12 fly trap attractant addition of organic waste, fish, and fermented soybean cake that has been decomposed for 7 days with 3 repetitions.

The results showed the mean number of house flies (Musca domestica) were caught on the fly trap with attractant organic waste 152 tail, fish tail 240, and 331 tail tempeh. ANOVA test results show the value of $\mathrm{p}=0.000<0.05$ means that there is a significant difference between the number of flies caught in three attractants, and based on the results of LSD is known that fermented soybean cake is the most effective attractants traps compared with organic waste and rotting fish attractant.
\end{abstract}

Keywords : attractant, house flies (Musca domestica)

Abstrak : Penelitian ini bertujuan untuk mengetahui efektifitas atraktan sampah organik, ikan, dan tempe pada fly trap terhadap jumlah lalat rumah yang tertangkap di Tempat Pelelangan Ikan (TPI) Pulau Baai Kota Bengkulu.

Metode penelitian adalah Quasi Expperiment (ekperimen semu) dengan desain penelitian Posttest Only Control Group Design. Analisis penelitian menggunakan uji One Way Anova dan dilanjutkan dengan uji LSD. Penelitian ini menggunakan 12 fly trap penambahan atraktan sampah organik, ikan, dan tempe yang telah dibusukkan selama 7 hari dengan 3 kali pengulangan.

Hasil penelitian menunjukkan jumlah rerata lalat rumah (musca domestica) yang tertangkap pada fly trap dengan atraktan sampah organik 152 ekor, ikan 240 ekor, dan tempe 331 ekor. Hasil uji anova menunjukkan nilai $\mathrm{p}=0,000<0,05$ artinya terdapat perbedaan yang bermakna jumlah lalat yang tertangkap diantara ketiga atraktan, dan berdasarkan hasil uji LSD diketahui atraktan tempe paling efektif digunakan sebagai atraktan pada flay trap dibandingkan atraktan sampah organik dan ikan busuk.

Kata Kunci : Atraktan dan Lalat rumah (Musca domestica)

Lalat merupakan serangga vektor penyebab penyakit perut seperti diare dan kolera, dimana kolera merupakan masalah kesehatan masyarakat terutama di negara berkembang seperti Afrika, Asia dan Amerika Selatan. Diperkirakan 5,5 juta kasus kolera terjadi setiap tahunnya di Asia dan Afrika (Depkes RI, 2008).

Lalat rumah (Musca domestica) merupakan jenis serangga pemakan segalanya (Omnivora). Lalat rumah (Musca domestica) sangat menyukai makanan yang dimakan oleh manusia, seperti gula, susu, makanan olahan, selain itu lalat juga memakan kotoran, darah serta bangkai ikan (Depkes RI, 2001).

Laporan tahunan Puskesmas Padang Serai (2010), menunjukkan bahwa penyakit diare menempati urutan tertinggi dari sepuluh penyakit di Puskesmas Padang Serai khususnya di kelurahan Sumber Jaya di sekitar Tempat Pelelangan Ikan (TPI), karena banyaknya tempat-tempat yang memungkinkan untuk perkembangbiakan lalat, salah satunya di RT 19 yang jaraknya kurang lebih $500 \mathrm{~m}$ berdekatan dengan lokasi Tempat Pelelangan Ikan (TPI) yang aktifitas sehari-harinya tidak terlepas dari kegiatan jual beli ikan. 
Hasil pengukuran pendahuluan tingkat kepadatan lalat yang dilakukan pada tanggal 20 januari 2013 selama satu hari di Tempat Pelelangan Ikan (TPI) Pelabuhan Pulau Baai Kota Bengkulu diperoleh hasil pengukuran di sekitar lokasi TPI Pelabuhan Pulau Baai didapatkkan populasi lalat lebih dari 21 ekor/block grill, sehingga dikategorikan populasi sangat padat dan perlu dilakukan upaya pengendalian lalat. Lokasi Tempat Pelelangan Ikan (TPI) ini tidak jauh dari permukiman penduduk, jarak antara Tempat Pelelangan Ikan (TPI) dengan permukiman penduduk kurang dari $500 \mathrm{~m}$. Menurut Suyono dan Budiman (2010) jarak terbang lalat mencapai 0,5-20 $\mathrm{km}$ sehingga dimungkinkan lalat dapat berpindah ke permukiman penduduk dan terjadi penularan penyakit. Cara lalat menularkan penyakit terjadi secara mekanis dimana kulit, tubuh dan kakinya yang kotor merupakan tempat menempelnya mikroorganisme yang kemudian hinggap ke makanan yang dimakan manusia dan menyebabkan gejala sakit pada bagian perut dan saluran pencernaan.

Iskandar (2001) menyatakan Fly trap merupakan metode pengendalian lalat secara fisik-mekanik berbentuk sangkar yang terbuat dari kawat kasa sebagai dinding, dan menggunakan antraktan. Jenis atraktan yang akan digunakan peneliti adalah sampah organik, ikan busuk, dan tempe busuk yang ditambahkan super traps.

Atraktan adalah bahan yang digunakan untuk menarik atau mendekatkan serangga agar masuk kedalam Fly trap yang digunakan untuk pengendalian lalat dewasa dan digunakan diluar rumah, diletakkan pada udara terbuka, tempat yang terang dan terhindar dari bayangbayang pohon (Marlena, 2010).

Untuk mengatasi kepadatan jumlah lalat rumah (Musca domestica) di TPI Pulau Baai diperlukan metode pengendalian berbasis masyarakat. Penelitian ini bertujuan untuk mengetahui efektifitas atraktan sampah organik, ikan, dan tempe pada fly trap terhadap jumlah lalat rumah
(Musca domestica) yang tertangkap di Tempat Pelelangan Ikan (TPI) Pulau Baai Kota Bengkulu.

\section{BAHAN DAN CARA KERJA}

Jenis Penelitian yang digunakan adalah Quasi Expperiment (ekperimen semu) dengan desain penelitian Postest Only Control Group Design (Notoadmodjo, 2010). Populasi penelitian adalah atraktan sampah organik, ikan dan tempe dan sebagai sampel adalah sampah organik, ikan dan tempe yang telah dibusukkan selama $4-7$ hari dengan berat masing-masing atraktan $13,5 \mathrm{~kg}$. Alat yang digunakan adalah fly trap yang terbuat dari susunan kayu dengan dinding kawat kassa dengan ukuran $50 \mathrm{~cm} \mathrm{x}$ $50 \mathrm{~cm}$ x $50 \mathrm{~cm}$ sebanyak 12 buah. Fly trap yang telah ditambahkan atraktan diletakkan pada 3 titik dengan jarak 12 meter di lokasi TPI Pulau Baai. Masing-masing titik diletakkan 3 buah fly trap dan 1 kontrol. Fly trap diletakkan pukul 15.00 sampai 17.30 WIB. Perhitungan lalat yang terperangkap dilakukan pada pukul 18.00 WIB dengan menggunakan counter. Untuk mendapatkan hasil yang baik maka dilakukan 3 kali pengulangan pada masing-masing perlakuan dan kontrol.

\section{HASIL}

Distribusi jumlah lalat yang tertangkap dengan variasi atraktan, seperti pada tabel 1:

Tabel 1. Jumlah Lalat yang Tertangkap pada Berbagai Variasi Atraktan

\begin{tabular}{cccc}
\hline \multirow{2}{*}{ Pengulangan } & \multicolumn{3}{c}{ Jenis Atraktan } \\
\cline { 2 - 4 } & $\begin{array}{c}\text { Sampah } \\
\text { Organik }\end{array}$ & Ikan & Tempe \\
\hline 1 & 210 & 280 & 450 \\
2 & 110 & 250 & 340 \\
3 & 130 & 195 & 254 \\
4 & 120 & 155 & 215 \\
5 & 150 & 240 & 356 \\
6 & 300 & 355 & 419 \\
7 & 125 & 305 & 446 \\
8 & 105 & 140 & 256 \\
9 & 115 & 235 & 240 \\
Jumlah (Ekor) & 1365 & 2155 & 2976 \\
Rerata (Ekor) & 152 & 240 & 331 \\
\hline
\end{tabular}


Tabel 1 diketahui jumlah rerata lalat yang tertangkap pada atraktan sampah organik 152 ekor, pada atraktan ikan busuk jumlah rerata lalat yang tertangkap 240 ekor, dan pada atraktan tempe busuk jumlah rerata lalat yang tertangkap 331 ekor. Hasil uji perbedaan jumlah lalat yang tertangkap dengan berbagai variasi atraktan, seperti pada tabel 2:

Tabel 2. Hasil Uji One Way Anova terhadap Lalat yang Tertangkap pada Berbagai Variasi Atraktan

\begin{tabular}{|c|c|c|c|c|}
\hline Variabel & Mean & Sd & $95 \% \mathrm{cl}$ & $\underset{\text { value }}{\mathbf{p}}$ \\
\hline $\begin{array}{l}\text { Sampah } \\
\text { Organik }\end{array}$ & 152 & 64,080 & $\begin{array}{l}102,41- \\
200,92\end{array}$ & \\
\hline Ikan & 240 & 69,302 & $\begin{array}{l}186,17- \\
292,71\end{array}$ & 0,000 \\
\hline Tempe & 331 & 92,956 & $\begin{array}{c}259,21- \\
402,12\end{array}$ & \\
\hline
\end{tabular}

Tabel 2 dapat disimpulkan bahwa ada perbedaan yang bermakna jumlah lalat yang tertangkap pada masing-masing atraktan dengan nilai $\mathrm{p}$ value $=0,000$. Selanjutnya untuk mengetahui rerata perbedaan jumlah lalat yang tertangkap pada tiga jenis atraktan maka dilakukan uji LSD (Least Significance Difference). Hasil uji LSD dapat dilihat pada tabel 3 :

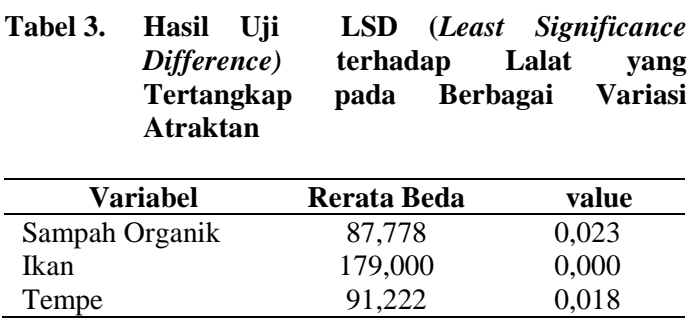

Berdasarkan Tabel 3, rerata beda terbesar jumlah lalat yang tertangkap pada atraktan sampah organik, ikan dan tempe adalah pada atraktan tempe yaitu sebesar 179,000 ekor dengan $\rho$ value $0,000<0,05$, hal ini berarti bahwa dari ketiga atraktan yang digunakan yang paling efektif adalah atraktan tempe.

\section{PEMBAHASAN}

Salah satu upaya pengendalian vektor lalat secara fisik-mekanik yaitu dengan menggunakan fly trap. Fly trap merupakan alat yang digunakan untuk pengendalian lalat khususnya lalat dewasa, dan pada penggunaannya digunakan atraktan sebagai umpan pemikat agar lalat masuk kedalam fly trap (Iskandar, 2001).

Atraktan adalah bahan yang digunakan untuk menarik atau mendekatkan lalat agar masuk kedalam perangkap (Iskandar, 2001). Banyak jenis atraktan yang dapat digunakan sebagai umpan pada perangkap lalat. Berdasarakan hasil analisis univariat rerata jumlah lalat yang tertangkap paling banyak pada atraktan tempe (331 ekor). Tempe busuk merupakan tempe kedelai yang telah mengalami proses fermentasi lanjut selama 7 hari sehingga warnanya abu-abu muda dan aromanya mirip dengan bau amonia. Adanya bau amonia tersebut, maka akan menarik perhatian lalat kemudian hinggap dan terperangkap. Selain itu tempe memiliki kandungan protein, karbohidrat, lemak, dan kalori yang tinggi. Protein merupakan makanan kesukaan lalat dan sering digunakan oleh lalat untuk meletakkan telurnya (Radiyati, 2002).

Hasil analisis bivariat rerata beda terbesar jumlah lalat yang tertangkap antara atraktan sampah organik, ikan dan tempe adalah pada atraktan tempe yaitu sebesar 179,000 ekor dengan $\rho=0,000<$ 0,05 , hal ini berarti bahwa dari ketiga atraktan yang digunakan yang paling efektif adalah atraktan tempe.

Penggunaan atraktan tempe pada fly trap lebih efektif karena pada atraktan ikan kandungan kadar air lebih sedikit sedangkan pada sampah organik bau amoniak yang ditimbulkan tidak begitu tajam dan kadar air tidak terlalu banyak sehingga lalat kurang tertarik pada kedua jenis atraktan tersebut. Pada atraktan tempe kadar air dan kandungan protein pada tempe lebih banyak serta bau amoniak yang ditimbulkan oleh tempe busuk sangat tajam, sehingga lalat lebih tertarik hinggap pada atraktan tempe busuk dibandingkan atraktan jenis ikan dan sampah organik. 
Penelitian ini sejalan dengan penelitian yang dilakukan oleh Suprapto (2003) yang berjudul efektifitas pengendalian lalat rumah (Musca domestica) menggunakan fly trap pada perimeter kantor kesehatan pelabuhan dumai. Pada penelitiannya jumlah kepadatan lalat sebelum dilakukan perlakuan menggunakan fly trap di pelabuhan Dumai diperoleh 4727 ekor, setelah dilakukan perlakuan dengan menggunakan fly trap tingkat kepadatan lalat tersebut turun menjadi 1997 ekor dengan waktu penelitian selama 5 hari.

Penggunaan fly trap dengan penambahan atraktan yang dilakukan di Tempat Pelelangan Ikan (TPI) Pelabuhan Pulau Baai Kota Bengkulu dapat membantu menurunkan tingkat kepadatan lalat. Hasil penelitian diperoleh jumlah kepadatan sebelum dilakukan perlakuan dengan menggunakan fly trap sebanyak 12.900 ekor, setelah dilakukan perlakuan dengan menggunakan fly trap diperoleh jumlah penurunan kepadatan lalat sebanyak 6496 ekor (52\%) dengan waktu penelitian selama 3 hari.

Penelitian ini sejalan dengan penelitian Kabul Budi Dwicahyo (2010) yang berjudul pengaruh penambahan formulasi tempe busuk sebagai atraktan pada kertas perekat lalat terhadap jumlah lalat rumah (Musca domestica) yang tertangkap.

Fly trap dengan penambahan atraktan tempe ini juga dapat dijadikan sebagai salah satu alat dalam mendukung program pengendalian lalat rumah (Musca domes-

\section{DAFTAR RUJUKAN}

Cahyo, Dwi. 2010. Pengaruh Penambahan Formulasi Tempe Busuk Sebagai Atraktan Pada Kertas Perekat Lalat Terhadap Jumalah Lalat Rumah (Musca domestica) Yang Tertangkap. Politeknik Kesehatan Kementerian Kesehatan Yogyakarta.

Depkes RI, 2001. Pedoman Teknis Pengendalian Lalat. Direktorat Jenderal PPM dan PLP, Jakarta.

Depkes RI, 2008. Pedoman Pengendalian Lalat Di Pelabuhan. Direktorat Jenderal PP \& PL, Jakarta. tica) secara fisik-mekanik karena tempe mudah didapatkan dan kandungan proteinnya dalam tempe sangat disukai oleh lalat untuk meletakkan telurnya. Kemudian cara pembuatan atraktan untuk pemikat lalat juga begitu mudah sehingga Fly Trap ini dapat diaplikasikan kepada masyarakat secara langsung.

\section{KESIMPULAN}

Berdasarkan hasil penelitian efektifitas atraktan sampah organik, ikan, dan tempe pada fly trap terhadap jumlah lalat rumah (Musca domestica) yang tertangkap di Tempat Pelelangan Ikan (TPI) Pulau Baai, menunjukkan bahwa: jumlah lalat rumah (Musca domestica) yang tertangkap menggunakan atraktan sampah organik sebanyak 1365 ekor, jumlah lalat rumah (Musca domestica) yang tertangkap dengan menggunakan atraktan ikan sebanyak 2255 ekor, jumlah lalat rumah (Musca domestica) yang tertangkap menggunakan atraktan tempe sebanyak 2760 ekor, dan ada perbedaan jumlah lalat yang tertangkap pada ketiga jenis atraktan.

Berdasarkan hasil penelitian, pembahasan dan kesimpulan, dapat disarankan agar masyarakat dapat melakukan pengendalian lalat dengan menggunakan alat yang sederhana, mudah dalam penggunaannya, bahan untuk pembuatannya sehingga masyarakat mampu mengatasi permasalahan yang disebabkan oleh binatang vektor khususnya lalat secara mandiri.

Dinas Perikanan Jawa Barat, 2008. Persyaratan Tempat Pelelangan Ikan.

Iskandar, 2001. Pemberantasan Serangga dan Binatang Pengganggu. Proyek Pengembangan dan Pendidikan Tenaga Sanitasi Pusat Departemen Kesehatan RI, Jakarta.

Notoatmojo, 2010. Kesehatan Masyarakat Ilmu Dan Seni. Rineka Cipta. Jakarta.

Santi, 2001. Manajemen Pengendalian Lalat. Fakultas Kedokteran Universitas Sumatera Utara. Sumatera. 
116 Jurnal Media Kesehatan, Volume 6, Nomor 2, Desember 2013, hlm 102-200

Sigit, dkk. 2006. Hama Permukiman Indonesia. Institut Pertanian Bogor. Bogor.

Slamet, 2000. Pola Hidup Lalat Rumah (Musca domestica). Nasional. Jakarta.

Sulthoni, dkk. 2008. Kunci Determinasi Serangga. Yogyakarta : Kanisius.

Suprapto, 2003. Efektifitas Pengendalian Lalat Rumah (Musca domestica) Dengan Menggunakan Fly Trap Pada Perimeter Kantor Kesehatan Pelabuhan Dumai. Universitas Sumatera Utara.

Supriono, 2003. Memproduksi Tempe. Departemen Pendidikan Nasional. Jakarta.

Suraini, 2011. Jenis-jenis Lalat (Diptera) Dan Bakteri Enterobacteriaceae Yang Terdapat
Di Tempat Pembuangan Akhir Sampah (TPA). Stikes Padang.

Wijayanti Putri, 2009. Hubungan Kepadatan Lalat Terhadap Sampah. Universitas Indonesia. Jakarta.

Winamo, 2006. Hama Gudang Dan Teknik Pemberantasanannya. M-Brio Press, Edisi Revisi. Bogor.

Winarno, dkk. 2005. Herbal Dan Rempah Aplikasinya Dalam Hidangan. M-Brio Press, Edisi Revisi. Bogor.

Yuliani, dkk. 2005. Efektifitas Lilin Penolak Lalat (Repelen) Dengan Bahan Aktif Limbah Penyulingan Minyak Nilam. FKH IPB. Jurnal Pasca Panen Vol: No 1 2005. Bogor. 